\title{
DASAR HUKUM DAN PRINSIP ASURANSI SYARIAH DI INDONESIA
}

\author{
Mukhsinun $^{1}$ dan Utihatli Fursotun ${ }^{2}$ \\ ${ }^{1,2}$ Institut Agama Islam Nahdlatul Ulama (IAINU) Kebumen \\ mukhsinun.kebumen@gmail.com
}

\begin{abstract}
ABSTARACT
Insurance is a non-bank financial institution whose function is to collect public funds to provide protection against risks of uncertainty resulting from disasters, accidents or other losses. One type of insurance is sharia insurance. Sharia insurance is an insurance system that is based on Islamic law in its service process and operation. Sharia insurance is a risk management arrangement that complies with sharia provisions, mutual assistance involving participants and operators. Sharia comes from provisions in the Qur'an and as-Sunnah. The emergence of sharia insurance in the Islamic world is based on the assumption that the existing insurance, namely conventional insurance, contains many elements: gharar, maisir, usury. This insurance has principles that are firmly held, namely ta'awunu 'ala al birr wa al-taqwa (please help all of you in kindness and piety) and al-ta'min (feeling of security).
\end{abstract}

Keywords: Sharia Insurance, Legal Basis of Sharia Insurance, Principles of Sharia Insurance

\begin{abstract}
ABSTRAK
Asuransi merupakan lembaga keuangan non bank yang berfungsi menghimpun dana masyarakat guna memberikan perlindungan resiko ketidakpastian yang diakibatkan terjadinya musibah, kecelakaan, atau kerugian lainnya. Salah satu jenis asuransi yaitu asuransi syariah. Asuransi syariah merupakan sistem asuransi yang berlandaskan syariat Islam dalam proses pelayanannya dan pengoperasiannya. Asuransi syariah adalah pengaturan pengelolaan risiko yang memenuhi ketentuan syariah, tolong menolong secara mutual yang melibatkan peserta dan operator. Syariah berasal dari ketentuan- ketentuan di dalam al-Qur'an dan as-Sunnah. Munculnya asuransi syariah di dunia islam di dasarkan adanya anggapan yang menyatakan bahwa asuransi yang ada selama ini, yaitu asuransi konvensional banyak mengandung unsur : gharar, maisir, riba. Asuransi ini memiliki prinsip-prinsip yang dipegang teguh yaitu ta'awunu 'ala al birr wa al-taqwa (tolong menolonglah kamu sekalian dalam kebaikan dan takwa) dan al-ta'min (rasa aman).
\end{abstract}

Kata kunci: Asuransi Syariah, Dasar Hukum Asuransi Syariah, Prinsip- prinsip Asuransi Syariah 


\section{PENDAHULUAN}

Kata "asuransi" banyak berasal dari Bahasa-bahasa asing diantaranya adalah: Bahasa Belanda "assurantie", yang berarti pertangungan, Bahasa Italia "insurensi", yang berarti jaminan, Bahasa Inggris "assurance", yang berarti jaminan, Bahasa Arab “At-ta'min", yang berarti perlindungan, ketenangan, rasa aman dan bebas dari rasa takut. ${ }^{1}$ Dari segi bahasa menurut Wirjono berarti sebuah persetujuan pihak, yang menjamin berjanji kepada pihak yang dijamin atas kerugian yang mungkin akan diderita oleh yang dijamin karena akibat dari sebuah peristiwa yang belum jelas terjadi.

a. Abbas Salim berarti suatu kemauan untuk menetapkan kerugiankerugian kecil (sedikit) yang sudah pasti sebagai (substitusi) kerugiankerugian yang belum pasti.

b. Syeikh Musthafa az-Zarqa berarti cara dalam menghindari risiko yang akan dihadapinya.

c. Ensiklopedi Hukum Islam berarti transaksi perjanjian antara dua pihak; pihak pertama berkewajiban untuk membayar iuran dan pihak lain berkewajiban memberikan jaminan sepenuhnya kepada pembayar iuran.

d. UU No. 2 thn 1992 pasal 1 berarti perjanjian antara dua pihak atau lebih dimana pihak penangung mengikatkan diri kepada tertanggung dengan menerima premi asuransi untuk memberikan pergantian kepada tertanggung karena suatu kerugian, kerusakan dan lain sebagainya.

Setelah memperhatikan beberapa definisi asuransi diatas, baik dari segi bahasa ataupun istilah, dapat disimpulkan bahwa dalam suatu perjanjian asuransi minimal terlibat pihak pertama yang sanggup menanggung atau menjamin bahwa pihak lain mendapatkan pergantian dari suatu kerugian yang mungkin akan di derita sebagai akibat dari suatu peristiwa yang semula belum tentu terjadi atau belum di tentukan saat akan terjadinya. ${ }^{2}$

Asuransi syariah adalah pengaturan pengelolaan risiko yang memenuhi

\footnotetext{
${ }^{1}$ Rodoni, Ahmad dan Hamid, Abdul, Lembaga Keuangan Syariah, (Zikrul Hakim: Jakarta), hal . 93

${ }^{2}$ Zainuddin ali, Hukum Asuransi Syariah (Sinar Grafika:Jakarta 2008), hal. 1
} 
ketentuan syariah, tolong menolong secara mutual yang melibatkan peserta dan operator. Syariah berasal dari ketentuan-ketentuan di dalam al-Qur'an dan asSunnah. ${ }^{3}$

Dalam perspektif ekonomi Islam, asuransi dikenal dengan istilah takaful yang berasal dari bahasa arab taka<fala-yataka<fulu-takaful yang berarti saling menanggung atau saling menjamin. Asuransi dapat diartikan sebagai perjanjian yang berkaitan dengan pertanggungan atau penjaminan atas resiko kerugian tertentu. ${ }^{4}$

Dari beberapa pengertian di atas, dapat kita ambil kesimpulan bahwasannya asuransi takaful merupakan pihak yang tertanggung penjamin atas segala risiko kerugian, kerusakan, kehilangan, atau kematian yang dialami oleh nasabah (pihak tertanggung). Dalam hal ini, si tertanggung mengikat perjanjian (penjaminan resiko) dengan si penanggung atas barang atau harta, jiwa dan sebagainya berdasarkan prinsip bagi hasil yang mana kerugian dan keuntungan disepakati oleh kedua belah pihak. ${ }^{5_{5}}$

Di Indonesia kita kenal ada bermacam-macam asuransi dan sebagai contoh dikemukakan dibawah ini, di antaranya:

1. Asuransi Beasiswa

Asuransi beasiswa mempunyai dasar dwiguna. Pertama jangankan pertanggungan dapat 5-20 tahun, disesuaikan dengan usia dan racana sekolah anak; kedua, jika ayah (tertanggung) meninggal dunia sebelum habis kontrak, pertanggungan menjadi bebas premi sampai habis kontrak polisnya. Tetapi jika anak yang ditunjuk meninggal, maka alternatifnya ialah mengganti dengan anak yang lainnya, mengubah kontrak kepada bentuk lainnya, menerima uangnya secara tunai, bila polisnya telah berjalan tiga tahun lebih, atau membatalkan perjanjian (sebelum tiga tahun belum ada harga tunai). Pembayaran beasiswa dimulai, bila kontrak sudah habis.

2. Asuransi Dwiguna

\footnotetext{
${ }^{3}$ Iqbal Muhaimin, Asuransi Umum Syariah dalam Praktik, (Jakarta: Gema Insani Press, 2005), 2.

${ }^{4}$ Hendi Suhendi dan Deni K Yusuf, Asuransi Takaful dari Teoritis Ke Praktik,(Bandung: Mimbar Pustaka, 2005), 1

5 Ibid, hal. 3-4.
}

LABATILA: Jurnal Ilmu Ekonomi Islam - Volume 3 Nomor 1 (2019) 
Asuransi dwiguna dapat diambil dalam jangka 10-15-25-30 tahun dan mempunyai dua guna: ${ }^{6}$

a. Perlindungan bagi keluarga, bilamana tertanggung meninggal dunia dalam jangka waktu pertanggungan..

b. Tabungan bagi tertanggung, bilamana tertanggung tetap hidup pada akhir jangka pertanggungan.

3. Asuransi Jiwa

Asuransi jiiwa adalah asuransi yang bertujuan menaggung orang terhadap kerugian finansial yang tidak tertuga yang disebabkan seseorang meninggal terlalu cepat atau hidupnya terlalu lama. Jadi ada dua hal yang menjadi tujuan asuransi jiwa ini, yaitu menjamin biaya hidup anak atau keluarga yang ditinggalkan, bila memegang polis meninggal dunia atau untuk memenuhi keperluan hidupnya dan keluarganya, bila ditakdirkan usianya lanjut sesudah masa kontrak berakhir.

4. Asuransi Kebakaran

Asuransi kebakaran bertujuan untuk mengganti kerugian yang disebabkan oleh kebakaran. Dalam hal ini pihak perusahaan asuransi menjamin risiko yang terjadi karena kebakaran. Oleh karena itu perlu dibuat suatu kontrak (perjanjian) antara pemegang polis (pembeli asuransi) dengan perusahaan asuransi.

Kalau kita perhatikan tujuan dari semua macam asuransi itu maka pada prinsipnya pihak perusahaan asuransi memperhatikan tentang masa depan kehidupan keluarga, pendidikannya dan termasuk janminan dari tua. Demikian juga perusahaan asuransi turut memikirkan dan berusaha untuk memperkecil kerugian yang mungkin timbul akibat erjadi resiko dalam melaksanakan kegiatan usaha baik terhadap kepentingan pribadi atau perusahaan.

Di kalangan umat Islam ada anggapan bahwa asuransi itu tidak Islami. Orang yang melakukan asuransi, sama halnya dengan orang yang mengingkari

\footnotetext{
${ }^{6}$ M.Ali.Hasan,Masail Fiqiyah Zakat, Pajak Asuransi dan Lembaga Keuangan, (Jakarta: PT Raja Grafindo
} Persada, 2000), hal. 58.

LABATILA: Jurnal Ilmu Ekonomi Islam - Volume 3 Nomor 1 (2019) 
rahmat Allah. Allah-lah yang menentukan segala-galanya dan yang memberikan rezeki kepada makhluk-Nya, sebagaimana firman Allah:

Dan tidak ada satu binatang melata pun di bumi melainkan Allah-lah yang memberi rezekinya (QS.Hud: 6).

.... dan siapa (pula) yang memberikan rezeki kepadamu dari langit dan bumi? Apakah disamping Allah ada Tuhan (yang lain)? .... (QS. An-Naml: 64).

Firman Allah:

Dan Kami telah menjadikan untukmu di bumi keperluan-

keperluan hidup, dan (Kami menciptakan pula), makhluk-makhluk yang

kamu sekali-kali bukan pemberi rezeki kepadanya. (QS al-Hijr:20).

Dari ketika ayat tersebut dapat dipahami bahwa Allah sebenarnya telah menyiapkan segala-galanya untuk keperluan semua makhluk-Nya, termasuk manusia sebagai khalifah di muka bumi. Allah telah menyiapkan bahan mentah, bukan bahan matang. Manusia masih pelru mengolahnya, mencarinya dan mengiktiarkannya. ${ }^{7}$

\section{METODE PENELITIAN}

Metode penelitian yang digunakan pada penelitan ini yaitu metode penelitiankaulitatif dengan pendekatan deskriptif dengan jenis penelitian literature review. literature revieuw yaitu mengumpulkan informasi atau karya tulis yang bersifat kepustakan. ${ }^{8}$ Pengumpulan informasi dilakukan dengan cara menelaah dari beberapa sumber tertulis yaitu jurnal, buku, dan sumber-sumber lainnya yang tentunya sesuai dengan objek penelitian

\section{HASIL DAN PEMBAHASAN}

\section{A. Berdirinya Asuransi Syariah di Indonesia}

Munculnya asuransi syariah di dunia islam di dasarkan adanya anggapan yang menyatakan bahwa asuransi yang ada selama ini, yaitu asuransi konvensional banyak mengandung unsur: gharar, maisir, riba.

a. Gharar (ketidakjelasan)

Gharar itu terjadi pada asuransi konvensional, dikarenakan

\footnotetext{
${ }^{7}$ Ibid, hal.58-60

${ }^{8}$ Muannif Ridwan, Suhar AM, dkk, pentingnya literature reviuw pada penelitian ilmaiah, mashohi, volume 2 nomor 1 , juli 2021, hal, 42-51
}

LABATILA: Jurnal Ilmu Ekonomi Islam - Volume 3 Nomor 1 (2019) 
tidak adanya batas waktu pembayaran premi yang didasarkan atas usia tertanggung. Jika baru sekali seorang tertanggung membayar premi ditakirkan meninggal, perusahaan asuransi akan rugi sementara pihak tertanggung merasa untung secara materi. Jika tertanggung dipanjangkan usianya, perusahaan asuransi akan untung dan pihak tertaggung merasa rugi secara financial.

b. Maisir (judi)

Unsur maisir dalam asuransi konvensional karena adanya unsur gharar, terutama dalamkasus asuransi jiwa. Apabila pemegang polis asuransi jiwa meninggal dunia sebelum periode akhir polis asuransinya dan telah membayar preminya sebagian, maka ahli waris akn menerima sejumlah uang tertentu. Pemegang polis tidak mengetahui bagaimana dan darimana cara perusahaan asuransi konvensional membayarkan uang pertanggungannya. Hal ini dipandang karena keuntungan yang diperoleh berasal dari keberanian mengambil resiko oleh persahaan yang bersangkutan. Yang disebut maisir disinijika perusahaan asuransi mengandalkan banyak sedikitnya klaim yang dibayarkannya.

c. Riba

Dalam hal riba semua asuransi konvensional menginvestasikan semua dananya dengan bunga, yang berarti selalu melibatkan diri dalam riba. Hal demikian juga dilakukan saat perhitungan kepada peserta, dilakukan dengan menghitung keuntungan didepan. Pernyataan yang serupa telah jauh-jauh di kumandangkan di Malaysia. Jawatan kuasa kecil malaysia menyatakan dalam kertas kerjanya yang berjudul "Ke arah Insurance secara Islami” di Malaysia. Bahwa asuransi masa kini mengikuti cara pengelolaan dari Barat dan sebagian operasinya tidak sesuai dengan ajaran islam. Atas landasan itulah kemudian dirumuskan bentuk asuransi yang terhindar dari ktiga unsur yang diharamkan islam itu.

Selanjutnya, pada dekadetahun 70-an, di beberapa Negara islam atau 
di Negara-negara yang mayoritas berpenduduk Muslim, mulai bermunculan asuransi yang prinsip opersionalnya mengacu pada nilai-nilai islam dan terhindar dari unsur-unsur yang diharamkan.

Pada tahun 1979, Islamic Insurance Co. Ltd berdiri di Sudan, Islamic Insurance Co. Ltd di Arab Saudi. Pada tahun 1983, berdiri Dar al-mal alIslami di Genewa dan Takaful Islam di Luxumburg, Takaful Islam Bahamas di Bahamas, dan at-Takaful al-Islami di Bahrian. Adapun di Negara tetangga yang paling dekat dengan Indonesia, yakni Malaysia, telah berdiri Syarikat Takaful Sendirian Berhad pada tahun 1984.

Sedangkan di Indonesia, asuransi Takaful baru muncul pada tahun 1994 seiring dengan diresmikannya PT. Asuransi Takaful Keluarga dan PT. Asuransi Takaful umum pada tahun 1995. Gagasan untuk mendirikan asuransi islam di Indonesia sebenarnya telah muncul sejak lama, dan pemikiran tersebut lebih menguat pada saat diresmikannya Bank Muamalat Indonesia pada tahun 1991. ${ }^{9}$

\section{B. Aspek Hukum Asuransi Syariah di Indonesia}

1. Dasar Hukum Asuransi Syariah

a. Al-Qur'an

Secara ekplisit tidak ada satu ayat pun dalam al-Qur'an yang menyebutkan istilah asuransi seperti yang kita kenal sekarang ini, baik istilah "al-ta'min" ataupun "al-takaful”. Akan tetapi dalam al-Qur'an terdapat ayat yang menjelaskan tentang konsep asuransi dan yang memiliki muatan nilai-nilai dasar yang ada dalam praktik asuransi. Mengenai ayat-ayat tersebut dapat diklasifikasikan menjadi empat macam kategori, yaitu:

1) Perintah Allah untuk mempersiapkan masa depan QS. AlHasyr: 18 yang artinya:

"Hai orang-orang yang beriman, bertawakallah kepada Allah dan hendaklah setiap diri memperhatikan apa yang dibuat untuk hari esok (masa depan). Dan bertawakalah kepada Allah

\footnotetext{
${ }^{9}$ http://www.anekamakalah.com/2013/02/makalah-asuransi-syariah.html
} 
sesungguhnya Allah Maha Mengetahui apa yang kamu kerjakan."

2) Perintah Allah untuk saling tolong-menolong dan bekerjasama QS. Al-Maidah: 2, yang artinya:

"...tolong menolonglah kamu dalam (mengerjakan) kebaikan dan takwa dan jangan tolong-menolong dalam berbuat dosa dan pelanggaran. Dan bertawakalah kamu kepada Allah, sesungguhnya Allah amat berat siksa-Nya." 11

QS. Al-Baqarah: 185, yang artinya:

“...Allah mengehendaki kemudahan bagimu, dan tidak mengehendaki kesukaran bagimu..."

3) Perintah Allah untuk saling melindungi antar sesame ketika menghadapi kesusahan QS. Al-Quraisy: 4, yang artinya:

"yang telah memberi makanan kepada mereka untuk menghilangkan lapar san mengamankan mereka dari ketakutan." 13

QS. Al-Baqarah: 126, yang artinya:

"Dan ketika Ibrahim berdoa, "Ya Tuhanku, jadikanlah negeri ini yang aman sentosa (selamat).",14

4) Perintah Allah untuk tawakal dan optimis dalam berusaha

QS. Al-Taghaabun: 11, yang artinya:

"Tidak ada sesuatu musibahpun yang menimpa seseorang kecuali dengan izin Allah..."

5) Penghargaan Allah terhadap perbuatan mulia yang dilakukan manusia

Terdapat dalam QS. Al-Baqarah ayat 261, yang artinya:

"Perumpamaan (nafkah yang dikeluarkan oleh) orang yang menafkahkan hartanya di jalan Allah adalah serupa dengan sebutir benih yang menumbuhkan tujuh bulir, pada tiap-tiap

\footnotetext{
${ }^{10}$ Departemen Agama RI, Al-Qur'an dan Terjemahnya, 799

${ }^{11}$ Ibid, hal.142.

${ }^{12}$ Ibid, hal.35

${ }^{13}$ Ibid, hal. 916

${ }^{14}$ Ibid, hal.23
}

LABATILA: Jurnal Ilmu Ekonomi Islam - Volume 3 Nomor 1 (2019) 
bulir serratus biji. Dan Allah Mahaluas (karunia-Nya) lagi Maha Mengetahui."

b. Hadis Nabi Muhammad SAW

1) Hadis tentang Aqilah

Diriwayatkan oleh Abu Hurairah r.a, dia berkata:

"Berselisih dua orang wanita dua orang wanita dari suku Huzail, kemudian salah satu wanita tersebut melempar batu ke wanita yang lain sehingga mengakibatkan kematian wanita tersebut beserta janin yang dikandungnya. Maka ahli waris dari wanita yang meninggal tersebut mengadukan peristiwa tersebut kepada Rasulullah saw, maka Rasulullah saw memutuskan ganti rugi dari pembunuhan terhadap janin tersebut dengan pembebasan seorang budak laki-laki atau perempuan, dan memutuskan ganti rugi kematian wanita tersebut dengan uang darah (diyat) yang dibayarkan oleh aqilahnya (kerabat dari orang tua laki-laki)". (HR. Bukhari $)^{15}$

Hadis di atas menjelaskan tentang praktik aqilah yang telah menjadi tradisi di masyarakat Arab. Aqilah dalam hadis di atas dimaknai dengan ashabah (kkerabat dari orang tua laki-laki) yang mempunyai kewajiban menanggung denda (diyat) jika ada salah atu anggota sukunya melakukan pembunuhan terhadap anggota suku lain. Penanggungan bersama oleh aqilah-nya merupakan suatu kegiatan yang mempunyai unsur seperti yang berlaku pada bisnis asuransi. Kemiripan ini didasarkan atas adanya prinsip saling menanggung (tafakul) antar anggota suku.

2) Hadis tentang anjuran menghilangkan kesulitan seseorang.

Diriwayatkan oleh Abu Hurairah r.a, Nabi Muhammad bersabda "Barang siapa yang menghilangkan kesulitan duniawinya seorang mukmin, maka Allah SWT akan menghilangkan kesulitanya pada hari kiamat. Barangsiapa yang mempermudah kesulitan seseorang, maka Allah SWT akan mempermudah urusannya di dunia dan di akhirat". (HR.

\footnotetext{
${ }^{15}$ Abdul Ghofur Anshori, Asuransi Syariah di Indonesia,(Yogyakarta: UII Press Yogyakarta), hal.31
} 
Muslim)

3) Hadis tentang anjuran meninggalkan ahli waris yang kaya Diriwayatkan dari Amir bin Sa'ad bin Abi Waqasy, telah bersabda Rasulullah SAW: "Lebih baik jika engkau meninggalkan anak-anak kamu (ahli waris) dalam keadaan miskin (kelaparan) yang meminta-minta kepada manusia lainnya." (HR. Bukhari)

4) Hadis tentang menghindari risiko

Diriwayatkan dari Anas bin Malik ra, bertanya seseorang kepada Rasulullah saw, tentang (untanya) :"Apa (unta) ini saya ikat saja atau langsung saya bertawakal pada Allah SWT. "Bersabda Rasulullah saw. : pertama ikatlah unta itu kemudian bertaqwalah kepada Allah SWT. (HR. at-Tirmizi).

c. Fatwa Sahabat

Praktik sahabat dalam pembayaran hukuman (ganti rugi) pernah dilaksanakan oleh khalifah kedua yaitu Umar bin Khattab. Beliau berkata: "Orang-orang yang namanya tercantum dalam diwan tersebut berhak menerima bantuan dari satu sama lain dan harus menyumbang untuk pembayaran hukuman (ganti rugi) atas pembunuhan (tidak sengaja) yang dilakukan oleh salah seorang anggota masyarakat mereka”. Umarlah orang yang pertama kali mengeluarkan perintah untuk menyiapkan daftar secara professional per wilayah, dan orang-orang yang terdaftar diwajibkan saling menanggung beban. ${ }^{16}$

d. Ijmak

Para sahabat telah melakukan ittifaq (kesepakatan) dalam hal aqilah yang dilakukan oleh Khalifah Umar bin Khattab. Adanya ijmak atau kesepakatan ini tampak dengan tidak adanya sahabat lain yang menentang pelaksanaan aqilah ini. Aqilah adalah iuran dana yang dilakukan oleh keluarga dari pihak laki-laki (asabah) dari si

\footnotetext{
${ }^{16}$ Ibid, hal. 33
}

LABATILA: Jurnal Ilmu Ekonomi Islam - Volume 3 Nomor 1 (2019) 
pembunuh (orang yang menyebabkan kematian secara tidak sewenang-wenang). Dalam hal ini, kelompoklah yang menanggung pembayarannya, karena si pembunuh merupakan anggota dari kelompok tersebut dengan tidak adanya sahabat yang menentang khalifah Umar bisa disimpulkan bahwa terdapat ijma dikalangan sahabat Nabi saw mengenai persoalan ini.

e. Qiyas

Yang dimaksud dengan qiyas adalah metode ijtihad dengan jalan menyamakan hukum suatu hal yang tidak terdapat ketentuannya di dalam al-Qur'an dan as-Sunnah dengan kasus lain yang hukumnya disebut dalam al-Qur'an dan as-Sunnah karena persamaan illat (penyebab atau alasannya). Dalam kitab Fathul Bari, disebutkan bahwa dengan datangnya Islam sistem aqilah diterima oleh Rasulullah saw menjadi bagian dari hukum Islam. Ide pokok dari aqilahadalah suku Arab zaman dulu yang harus siap untuk melakukan kontribusi finansial atas nama si pembunuh, untuk membayar ahli waris korban kesiapan untuk membayar kontribusi keuangan ini sama dengan pembayaran premi ide praktik asuransi syariah ini. Dalam hal ini praktik yang mempunyai nilai sama dengan asuransi adalah praktik aqilah. Aqilah adalah iuran darah yang dilakukan oleh keluarga dari pihak laki-laki si pembunuh. ${ }^{17}$

\section{Istihsan menurut bahasa adalah menganggap baik sesuatu.}

Menurut istilah menurut ulama ushul adalah beralihnya pemikiran seseorang mujtahid dari tuntutan qiyas yang nyata kepada qiyas yang samar atau dari hukum umum kepada perkecualian karena ada kesalahan pemikiran yang kemudian memenangkan perpindahan itu. Seperti halnya kebaikan dari kebiasaan aqilah di kalangan Arab kuno yang terletak pada kenyataan bahwa ia dapat menggantikan balas dendam berdarah.

Muslehuddin mengatakan manfaat signifikasi dari praktik aqilah tersebut adalah :

\footnotetext{
${ }^{17}$ Ibid, hal.33-34
}

LABATILA: Jurnal Ilmu Ekonomi Islam - Volume 3 Nomor 1 (2019) 
1. Mempertahankan keseimbangan kesukuan dan dengan demikian, kekuatan pembalasan dendam dari setiap suku dapat menghalangi kekejaman anggota suku lain.

2. Menambah sebagian besar jaminan sosial, karena mengingat tanggung jawab kolektif untuk membayar ganti rugi, suku harus menjaga seluruh kegiatan anggota sesamanya.

3. Mengurangi beban anggota perorangan jika ia membayar ganti rugi.

4. Menghindarkan dendam darah yang mengakibatkan kehancuran total.

5. Mempertahankan sepenuhnya kesatuan darah dan kerjasama para anggota dari setiap suku, yang tak lain merupakan mutualitas (saling membantu). ${ }^{18}$

\section{Prinsip-Prinsip Asuransi Syariah}

Prinsip utama dalam asuransi syaiah adalah ta'awunu 'ala al birr wa al-taqwa (tolong menolonglah kamu sekalian dalam kebaikan dan takwa) dan al-ta'min (rasa aman). Prinsip ini menjadikan para anggota atau peserta asuransi sebagai sebuah keluarga besar yang satu dengan lainnya saling menjamin dan menanggung risiko. Hal ini disebabkan transaksi yang dibuat dalam asuransi syariah adalah akad takafuli (saling menanggung), bukan akad tabaduli (saling menukar) yang selama ini digunakan oleh asuransi konvensional, yaitu pertukaran pembayaran premi dengan uang pertanggungan. Prinsip dasar asuransi syariah adalah:

1. Tauhid (Unity)

Prinsip tauhid (unity) adalah dasar utama dari setiap bentuk bangunan yang ada dalam syariat Islam. Setiap Bangunan dan aktivitas kehidupan manusia harus didasarkan pada nilai-nilai tauhid. Artinya bahwa dalam setiap gerak langkah serta bangunan hukum harus mencerminkan nilai-nilai ketuhanan.

\section{Keadilan (justice)}

Prinsip kedua dalam beransuransi adalah terpenuhinya nilai-nilai keadilan (justice) antara pihak-pihak yang terikat dengan akad asuransi.

\footnotetext{
${ }^{18}$ Dzajuli dan Yadi Jazwari, Lembaga-lembaga Perekonomian Umat (Sebuah Pengenalan), (Jakarta: PT RajaGrafindo Persada, 2002), 131.
} 
Keadilan dalam hal ini dipahami sebagai upaya dalam menempatkan hak dan kewajiban antara nasabah dan perusahaan asuransi.

3. Tolong-menolong (ta'awun)

Prinsip dasar yang lain dalam melaksanakan kegiatan berasuransi harus didasari dengan semangat tolong-menolong (ta'awun) antara anggota. Seseorang yang masuk asuransi, sejak awal harus mempunyai niat dan motivasi untuk membantu dan meringankan beban temannya yang pada suatu ketika mendapatkan musibah atau kerugian.

4. Kerja sama (cooperation)

kerja sama merupakan prinsip universal yang selalu ada dalam literatur ekonomi Islam. Manusia sebagai makhluk yang mendapatkan mandat dari Khaliq-nya untuk mewujudkan perdamaian dan kemakmuran di muka bumi mempunyai dua wajah yang tidak dapat dipisahkan satu sama lainnya, yaitu sebagai makhluk individu dan sebagai makhluk sosial.

\section{Amanah (trustworthy)}

Prinsip amanah dalam organisasi perusahaan dapat terwujud dalam nilai-nilai akuntabilitas (pertanggung jawaban) perusahaan melalui penyajian laporan keuangan tiap periode. Dalam hal ini perusahaan asuransi harus memberi kesempatan yang besar bagi nasabah untuk mengakses laporan keuangan perusahaan. Laporan keuangan yang dikeluarkan oleh perusahaan asuransi harus mencerminkan nilai-nilai kebenaran dan keadilan dalam bermuamalah dan melalui auditor public.

6. Kerelaan (al-ridha)

Dalam bisnis asuransi, kerelaan dapat diterapkan pada setiap anggota (nasabah) asuransi agar mempunyai motivasi dari awal untuk merelakan sejumlah dana (premi) yang disetorkan keperusahaan asuransi, yang difungsikan sebagai dana sosial. Dan dana sosial memang betul-betul digunakan untuk tujuan membantu anggota (nasabah) asuransi yang lain jika mengalami bencana kerugiaan.

7. Larangan riba 
Ada beberapa bagian dalam al-Qur'an yang melarang pengayaan diri cara yang tidak dibenarkan. Islam menghalalkan perniagaan dan melarang riba.

\section{Larangan maisir(judi)}

Antonio mengatakan bahwa unsur maisir(judi) artinya adanya salah satu pihak yang untung namun di lain pihak justru mengalami kerugian. Hal ini tampak jelas apabila pemegang polis dengan sebabsebab tertentu membatalkan kontraknya sebelum masa reversing period, biasanya tahun ketiga maka yang bersangkutan tidak akan menerima kembali uang yang telah dibayarkan kecuali sebagaian kecil saja. Juga adanya unsur keuntungan yang dipengaruhi oleh pengalaman underwriting,di mana untung-rugi terjadi sebagai hasil dari ketetapan.

Dari kutipan Dictionary of Islam menerangkan bahwa, pada zaman dulu jika salah satu anggota suku yang terbunuh oleh suku lain, keluarga korban akan dibayar oleh saudara terdekat dari pembunuh (aqilah) sebagai kompensasi (diyat). Praktek aqilah sebelum Islam tetap diterima pada zaman Rasulullah sebagai bagian dari Hukum Islam. ${ }^{19}$ Meskipun konteks pertanggungan membayar tebusan (diyat) pada riwayat tersebut terkait dengan pelanggaran (jarimah), namun tidak tertutup kemungkinan berlaku pada kehidupan sosial ekonomi. Bukankah dalam muamalah terdapat akad-akad tertentu yang memberikan jaminan/ tanggungan kepada pihak lain yang sedang mengalami kesulitan.

Untuk melindungi harta dan jiwa akibat bencana, semua membutuhkan keberadaan lembaga asuransi yang dijalankan sesuai prinsip syariah. Dalam hukum syariah, dijumpai berbagai macam akad yang dapat diaplikasikan ke dalam bentuk perusahaan asuransi seperti halnya lembaga keuangan lainnya. Para ahli hukum Islam kontemporer menyadari sepenuhnya, bahwa status hukum asuransi syariah belum pernah ditetapkan oleh para pemikir hukum Islam dahulu (fuqaha). Pemikiran asuransi syariah seperti yang berlaku

\footnotetext{
${ }^{19}$ Zainuddin Ali, Hukum Asuransi Syariah, h. 9
} 
sekarang ini, merupakan hasil pergumulan antara pemahaman hukum syariat dengan realitas yang terjadi. Namun apabila dicermati melalui kajian secara mendalam, maka ditemukan bahwa pada asuransi terdapat maslahat sehingga para ahli hukum Islam (kontemporer) mengadopsi manajemen asuransi berdasarkan prinsip-prinsip syariah.

\section{E. Rukun dan Syarat Asuransi Syariah}

Menurut Mazhab Hanafi, rukun kafalah (asuransi) hanya ada satu, yaitu ijab dan qabul. Sedangkan menurut para ulama lainnya, rukun dan syarat kafalah (asuransi) adalah sebagai berikut:

1. Kaf'il (orang yang menjamin), dimana persyaratannya adalah sudah baligh, berakal, tidak dicegah membelanjakan hartanya dan dilakukan dengan kehendaknya sendiri.

2. Makful lah(orang yang berpiutang), syaratnya adalah bahwa yang berpiutang diketahui oleh orang yang menjamin. Disyaratkan dikenal oleh penjamin karena manusia tidak sama dalam hal tuntutan, hal ini dilakukan demi kemudahan dan kedisiplinan.

3. Makful 'anhu, adalah orang yang berutang.

4. Makful bih(utang, baik barang maupun orang), disyaratkan agar dapat diketahui dan tetap keadaannya, baik sudah tetap maupun akan tetap. ${ }^{20}$

Murtadha Muthahhari mengatakan bahwa asuransi merupakan suatu akad, yaitu suatu tindakan yang dalam kewenangan dua pihak (nasabah dan perusahaan asuransi). Lebih lanjut beliau menambahkan bahwa terdapat persyaratan dan larangan bagi sahnya suatu akad. Akad yang tidak memenuhi salah satu dari persyaratan ini atau melanggar dari salah satu larangan ini adalah batal. Adapun akad yang memenuhi semua persyaratan dan tercegah dari semua larangan, maka akad itu adalah sah, meskipun akad itu merupakan akad yang baru. Di antara sejumlah persyaratan itu misalnya:

1. Baligh (dewasa).

2. Berakal, sudah barang tentu setiap transaksi yang dilakukan oleh

\footnotetext{
${ }^{20}$ Hendi Suhendi, Fiqh Muamalah, (Jakarta: Raja Grafindo Persada, 2005), hal. 191
} 
orang yang kehilangan akal adalah tidak sah, maka perasuransiannya pun batal.

3. Ikhtiyar (kehendak bebas), tidak boleh ada paksaan dalam transaksi yang tidak disukai.

4. Tidak sah transaksi atas suatu yang tidak diketahui. Syarat ini terdapat di dalam seluruh transaksi. Tidak sah jual beli apabila barang yang di jual tidak diketahui, dan tidak sah pembayaran harga atas sesuatu yang tidak diketahui. Karena transaksi tersebut seperti perjudian.

5. Tidak sah transaksi yang mengandung unsur riba.

Ini adalah persyaratan dan larangan bagi sahnya transaksi. Atas dasar ini, maka setiap transaksi yang baru harus kita anggap sah, sesuai tuntutan prinsip.

\section{F. Jenis-Jenis Asuransi Syariah}

Asuransi syariah terdiri dari dua jenis yaitu:

1. Takaful Keluarga (Asuransi Jiwa) adalah bentuk asuransi syariah yang memberikan perlindungan dalam menghadapi musibah kematian dan kecelakaan atas diri peserta asuransi takaful. Produk asuransi takaful keluarga meliputi:
a. Takaful berencana
b. Takaful pembiayaan
c. Takaful pendidikan
d. Takaful dana haji
e. Takaful berjangka
f. Takaful kecelakaan siswa
g. Takaful kecelakaan diri
h. Takaful khairat keluarga

2. Takaful Umum (asuransi Kerugian) adalah bentuk asuransi syariah yang memberikan perlindungan finansial dalam menghadapi bencana atau kecelakaan atas harta benda milik peserta takaful. Produk-produk asuransi Tafakul umum adalah:

a. Tafakul kebakaran 
b. Tafakul kendaraan bermotor

c. Tafakul pengangkutan

d. Tafakul resiko pembangunan

e. Tafakul resiko pemasangan

f. Tafakul penyimpanan uang

g. Tafakul gabungan

h. Tafakul aneka

i. Tafakul rekayasa/enginering

\section{G. Ihktilaf Ulama yang Membolehkan}

Asal usul asuransi syariah berbeda dengan sejarah asuransi konvensional. $^{21}$ Lembaga asuransi sebagaimana dikenal sekarang sesungguhnya tidak dikenal pada masa awal Islam, akibatnya banyak literature Islam menyimpulkan bahwa asuransi tidak dapat dipandang sebagai praktek yang halal. Meskipun istilah asuransi secara jelas belum dikenal pada masa Islam, namun terdapat beberapa aktivitas dari kehidupan masa Rasulullah yang mengarah pada kegiatan asuransi. Misalnya konsep tanggung jawab bersama yang dikenal dengan sebutan aqilah ${ }^{22}$. Aqilah merupakan system menghimpun anggota untuk menyumbang dalam suatu tabungan bersama yang disebut kunz. Tabungan ini berujuan untuk memberikan pertolongan kepada keluarga korban yang terbunuh secara tidak sengaja atau untuk membebaskan hamba sahaya. ${ }^{23}$

Asuransi Ada baiknya, kita mengutip pandangan ulama Islam terhadap eksistensi asuransi pada masa-masa awal sehingga melahirkan satu konsep yang disebut dengan asuransi takaful. Tujuannya sama dengan asuransi, namun beda dalam banyak praktek dan teori. Yang paling mengemuka dari pendapat-pendapat tersebut terbagi tiga, yaitu: pertama, Mengharamkan. Asuransi itu haram dalam segala macam bentuknya, temasuk asuransi jiwa. Pendapat ini dikemukakan oleh Sayyid Sabiq, 'Abd Allâh al-Qalqi (mufti Yordania), Yusuf Qaradhâwi dan Muhammad Bakhil

${ }^{21}$ Zainuddin Ali, Hukum Asuransi Syariah, h. 9

${ }^{22}$ Gemala Dewi, Aspek-Aspek Hukum dalam Perbankan dan Perasuransian Syariah di Indonesia, (Jakarta: Prenada Media, 2004), h. 123

${ }^{23}$ Rahmat Husein, Asuransi Takaful Selayang Pandang dalam Wawasan Islam dan Ekonomi, h. 234 
al-Muth'I (mufti Mesir). Alasan-alasan yang mereka kemukakan ialah:

a. Asuransi sama dengan judi;

b. Asuransi mengandung unsur-unsur tidak pasti;

c. Asuransi mengandung unsur riba/renten;

d. Asurnsi mengandung unsur pemerasan, karena pemegang polis, apabila tidak bisa melanjutkan pembayaran preminya, akan hilang premi yang sudah dibayar atau dikurangi;

e. Premi-premi yang sudah dibayar akan diputar dalam praktik-praktik riba;

f. Asuransi termasuk jual beli atau tukar menukar mata uang tidak tunai.

Hidup dan mati manusia dijadikan objek bisnis, dan sama halnya dengan mendahului takdir Allah. Kedua, Membolehkan. Pendapat kedua ini dikemukakan oleh Abd. Wahab Khallaf, Mustafa Akhmad Zarqa (guru besar Hukum Islam pada fakultas Syariah Universitas Syria), Muhammad Yûsuf Musa (guru besar Hukum Isalm pada Universitas Cairo Mesir), dan 'Abd Rahman 'Isa (pengarang kitab al-Muamalah al-Haditsah wa Ahkâmuha). Mereka beralasan:

a. Tidak ada nas (Alquran dan Sunnah) yang melarang asuransi;

b. Ada kesepakatan dan kerelaan kedua belah pihak;

c. Saling menguntungkan kedua belah pihak;

d. Asuransi dapat menanggulangi kepentingan umum, sebab premi-premi yang terkumpul dapat di investasikan untuk proyek-proyek yang produktif dan pembangunan;

e. Asuransi termasuk akad mudhârbah (bagi hasil);

f. Asuransi termasuk koperasi (syirkah ta'âwuniyah);

g. Asuransi dianalogikan (qiyas) dengan sistem pensiun seperti taspen. ${ }^{24}$ Ketiga, Asuransi sosial dibolehkan dan asuransi komersial diharamkan. Pendapat ketiga ini dianut antara lain oleh Muhammad Abû Zahrah (guru besar Hukum Islam pada Universitas Kairo). Alasan kelompok ketiga ini sama dengan kelompok pertama dalam asuransi.

\section{KESIMPULAN}

Diantara lembaga keuangan di Indonesia yang juga telah mengadopsi

\footnotetext{
${ }^{24}$ Zarqâ, Musthafâ Ahmad, al-Ta’mîm fi al-Islâm, h. 209.
} 
prinsip-prinsip syariah adalah lembaga perasuransian. Perasuransian berbasis syariah seperti yang berlaku sekarang ini, merupakan hasil pergumulan pemikiran antara pemahaman terhadap hukum syariat dengan realitas yang terjadi. Pencantuman istilah "syariah" pada lembaga perasuransian tentunya bukanlah sekedar label, karena keberadaanya pasti menuntut adanya perubahan. Perubahan itu diawali dengan penerapan akad-akad syariah ke dalam praktik asuransi sebagaimana telah difatwakan DSN-MUI hingga dari aspek regulasinya. Pada umumnya sasaran yang dijadikan sebagai objek perubahan, termasuk di bidang perasuransian, ialah hal-hal yang bersifat prinsip karena terkait langsung dengan halal-haram.

Prinsip-prinsip akad yang paling utama diterapkan pada lembaga perasuransian yaitu mudharabah, musyarakah, wakalah bil 'ujrah, dan hibah,sehingga diharapkan dapat terhindar dari praktik riba, maisir, gharar, insurance). Pengelolaan dana asuransi jiwa secara umum menggunakan dua pendekatan, yaitu pengelolaan dana dengan unsur tabungan (saving) yang disebut dana investasi, atau pengelolaan dana dengan unsur non tabungan (non saving) yang disebut dana tabarru'. Melalui produk tabungan, setiap premi takaful yang telah diserahkan kepada perusahaan asuransi akan dimasukkan ke dalam dua rekening secara terpisah zulmu, riswah, serta maksiat. Penerapan prinsip syariah dapat dilakukan baik asuransi jiwa (life insurance) maupun asuransi kerugian yang bersifat umum (general insurance). Pengelolaan dana asuransi jiwa secara umum menggunakan dua pendekatan, yaitu pengelolaan dana dengan unsur tabungan (saving) yang disebut dana investasi, atau pengelolaan dana dengan unsur non tabungan (non saving) yang disebut dana tabarru'. Melalui produk tabungan, setiap premi takaful yang telah diserahkan kepada perusahaan asuransi akan dimasukkan ke dalam dua rekening secara terpisah.

\section{DAFTAR PUSTAKA}

Ali, Zainuddin. 2008. Hukum Asuransi Syariah. Jakarta : Sinar Grafika. Antonio, Muhammad Syafii, "Prinsip Dasar Operasi Asuransi Takaful" dalam Arbitrase Islam di Indonesia, Jakarta: Badan Arbitrase Muamalat Indonesia, 1994 
Anshori, Abdul Ghofur. Asuransi Syariah di Indonesia. Yogyakarta: UII Press Yogyakarta).

Departemen Agama RI, Al-Qur'an dan Terjemahnya, 799

Dewi, Gemala, Aspek-Aspek Hukum dalam Perbankan dan Perasuransian Syariah di Indonesia, (Jakarta: Prenada Media, 2004

Dzajuli, Yadi Jazwari. 2002. Lembaga-lembaga Perekonomian Umat (Sebuah Pengenalan). Jakarta: PT Raja Grafindo Persada.

Hasan, M.Ali. 2000. Masail Fiqiyah Zakat, Pajak Asuransi dan Lembaga Keuangan. Jakarta: PT Raja Grafindo Persada.

Husein, Rahmat, Asuransi Takaful Selayang Pandang dalam Wawasan Islam dan Ekonomi, (Jakarta: Lembaga Penerbit FE-UI, 1997Muhaimin, Iqbal. 2005. Asuransi Umum Syariah dalam Praktik. Jakarta: Gema Insani Press.

Rodoni, Ahmad, Abdul Hamid. Lembaga Keuangan Syariah. Jakarta : Zikrul Hakim.

Suhendi, Hendi, Deni K Yusuf. 2005. Asuransi Takaful dari Teoritis Ke Praktik. Bandung: Mimbar Pustaka.

Suhendi, Hendi. 2005. Fiqh Muamalah. Jakarta: Raja Grafindo Persada. 